• 研究报告・

\title{
杭州湾内外海域秋季浮游动物群落的比较
}

\author{
张冬融 ${ }^{1,2}$ 徐兆礼 ${ }^{1 *}$ 徐佳奕 ${ }^{1}$ 董开兴 1,3 \\ 1 (中国水产科学研究院东海水产研究所农业部海洋与河口渔业重点开放实验室, 上海 200090) \\ 2 (国家海洋局第二海洋研究所工程海洋学重点实验室, 杭州 310012) \\ 3 (厦门大学海洋与地球学院, 福建厦门 361102)
}

\begin{abstract}
摘要: 本文比较了杭州湾湾外海域 $\left(122.10^{\circ}-122.58^{\circ} \mathrm{E}, 30.54^{\circ}-30.93^{\circ} \mathrm{N}\right)$ 和湾内不同海域(北岸东侧: $121.67^{\circ}-$ $121.87^{\circ} \mathrm{E}, 30.68^{\circ}-30.83^{\circ} \mathrm{N}$; 南岸东侧: $121.60^{\circ}-121.85^{\circ} \mathrm{E}, 29.95^{\circ}-30.24^{\circ} \mathrm{N}$; 北岸西侧: $121.31^{\circ}-121.56^{\circ} \mathrm{E}, 30.58^{\circ}-$ $\left.30.77^{\circ} \mathrm{N}\right)$ 秋季浮游动物的群落组成、累积优势度曲线以及多样性指数 $\left(H^{\prime}\right)$ 等群落结构特征, 并进行了差异性分析。 结果表明: 湾外海域的群落组成与湾内海域的 3 个群落之间均有较大的差异。湾外海域的群落I是以中华假磷虾 (Pseudeuphausia sinica) 等近海种、背针胸刺水蚤(Centropages dorsispinatus)等沿岸低盐种为主, 其次是外海种。湾 内南岸东侧海域的群落II主要以左突唇角水蚤(Labidocera sinilobata) 等沿岸低盐种为主, 近海种次之。湾内北岸东 侧海域的群落III是以真刺唇角水蚤(Labidocera euchaeta)等沿岸低盐种、虫肢歪水蚤(Tortanus vermiculus)等河口半 咸水种组成的混合群落。湾内北岸西侧海域群落IV是以虫肢歪水蚤为代表的河口半咸水种为主的群落。总的说来, 这一水域向西和向北方向出现更低盐度适应性的群落。从累积优势度曲线来看, 湾外海域群落I与湾内北岸东侧群 落III的累积优势度上升趋势均相对平缓, 但群落III的初始累积优势度略高于群落I; 而与群落I相比, 湾内南岸东 侧的群落II与北岸西侧的群落IV的初始累积优势度均很高。湾外海域群落I的初始累积优势度较低, 显示出群落I 的优势种较多, 而单一优势种优势度低于湾内 3 个群落。方差分析结果表明: 湾外海域的浮游动物多样性指数与湾 内 3 个海域均有极显著差异 $(P<0.01)$, 而湾内各海域之间均无显著性差异 $(P>0.05)$ 。说明湾外浮游动物群落的多 样性高于湾内海域。湾内外海域浮游动物群落特征之间有较大差异, 其主要原因是影响各自群落的主导水团明显 不同。
\end{abstract}

关键词: 杭州湾; 群落; 累积优势度; 浮游动物; 多样性

\section{Comparison of zooplankton communities inside and outside the Hang- zhou Bay in autumn}

\author{
Dongrong Zhang ${ }^{1,2}$, Zhaoli $\mathrm{Xu}^{1 *}$, Jiayi $\mathrm{Xu}^{1}$, Kaixing Dong ${ }^{1,3}$ \\ 1 Key and Open Laboratory of Marine and Estuary Fisheries, Ministry of Agriculture of China, East China Sea Fisheries \\ Research Institute, Chinese Academy of Fishery Sciences, Shanghai 200090 \\ 2 Key Laboratory of Engineering Oceanography, Second Institute of Oceanography, State Oceanic Administration, Peo- \\ ple's Republic of China, Hangzhou 310012 \\ 3 College of Ocean \& Earth Science, Xiamen University, Xiamen, Fujian 361102
}

\begin{abstract}
We analyzed and compared the differences in community composition, $K$-dominance curves and diversity index $\left(H^{\prime}\right)$ of zooplankton community structure characteristics inside and outside the Hangzhou Bay in autumn (outside the bay: $122.10^{\circ}-122.58^{\circ} \mathrm{E}, 30.54^{\circ}-30.93^{\circ} \mathrm{N}$; inside the bay: the east area of north: $121.67^{\circ}-121.87^{\circ} \mathrm{E}, 30.68^{\circ}-30.83^{\circ} \mathrm{N}$; the east area of south: $121.60^{\circ}-121.85^{\circ} \mathrm{E}, 29.95^{\circ}-30.24^{\circ} \mathrm{N}$; the west area of north: $121.31^{\circ}-121.56^{\circ} \mathrm{E}, 30.58^{\circ}-30.77^{\circ} \mathrm{N}$ ). Results indicated that there were large differences between the community composition of zooplankton outside the bay and those in the three areas inside the bay. The area outside the bay (community I) was composed of nearshore species such as Pseudeuphausia sinica and nearshore low-salinity species such as Centropages dorsispinatus, followed by offshore species. Com-
\end{abstract}

收稿日期: 2015-09-15; 接受日期: 2016-03-11

基金项目: 国家自然科学基金(41176131)和海洋公益性行业科研专项经费项目(201305027)

* 通讯作者 Author for correspondence. E-mail: xiaomin@sh163.net 
munity II (the eastern area of south Hangzhou Bay) was composed of nearshore low-salinity species such as Labidocera sinilobata, followed by nearshore species. Community III (the eastern area of north Hangzhou Bay) was mixed with nearshore low-salinity species such as Labidocera euchaeta and estuarine brackish-water species such as Tortanus vermiculus. Community IV (the western area of north Hangzhou Bay) was characterized by the dominant species, Tortanus vermiculus of estuarine brackish-water species that had the highest proportion, which was different from the community I. Generally, the community with lower salinity adaptability appeared in the western and northern areas. According to $K$-dominance curves, the dominance curves of community I and community III were quite gentle. In addition, the initial cumulative dominance of community III was higher than that of community I. Compared with community I, the initial cumulative dominance of community II and community IV were far higher than that of community I. The initial cumulative dominance of community I (outside the bay) was particularly low, which indicated that there were many types of dominant species in community I, and the dominance of single dominant species was lower than those communities inside the bay. Results of variance analysis indicated that there were highly significant differences between the diversity index of zooplankton outside the bay and those in the other three waters inside the bay $(P<0.01)$. Meanwhile, there were no significant differences between the three communities inside the bay $(P>0.05)$. This showed that the diversity index of zooplankton outside the bay was higher than those of the communities inside the bay. The influence of different water masses resulted in zooplankton community differences in the inner and outer waters of the bay.

Key words: Hangzhou Bay; community; cumulative dominance; zooplankton; diversity

杭州湾是一个典型的潮汐性海湾, 西有钱塘江 径流注入, 北受长江径流影响, 东部和湾口为东海 外海水和湾内水团交汇地, 湾外海域更多地受到东 海外海水团的影响(林丙尧和曹颖, 2000)。已有研究 表明，杭州湾内、外海域生态环境有很大不同，水 体环境的复杂性有可能造成杭州湾内外海域浮游 动物群落的差异, 因而有必要将湾外海域与湾内不 同水体浮游动物进行比较, 这样才能全面考察杭州 湾内外浮游动物的差异性。

早年朱启琴(1988)对杭州湾、长江口海域浮游 动物整体进行了研究, 但没有比较不同海域浮游动 物群落的差异性; 徐兆礼等 (2003b)、纪焕红等 (2004)、毕亚梅等(2010)、陈华和徐兆礼(2010)对杭 州湾不同水域浮游动物的研究, 也都局限于杭州湾 内某一小范围的水域; 俞存根等(2011)和陈小庆等 (2010)通过海洋生态系统综合调查, 研究了位于杭 州湾湾外的舟山渔场及邻近海域浮游动物的种类 组成、数量分布及群落结构等特征。综上, 我国对 于杭州湾湾内与湾外海域浮游动物群落的比较研 究尚未见到报道。国外对海湾内外海域浮游动物的 比较研究也不多, 如Govindan等(1977)对卡奇湾内 外海域浮游动物的生物量和种类组成进行了比较 研究, 但仅限于生物量和种类组成, 对群落结构的 比较几乎没有; Badylak和Philps (2008)研究发现,
佛罗里达州坦帕湾湾内的浮游动物丰度高于湾内 中部和湾外海域, 也没有比较湾内外浮游动物的群 落结构。

本文通过对杭州湾内外海域的浮游动物群落 进行调查，籍此探讨浮游动物群落对环境变化的响 应，以期丰富我国海湾海洋环境与浮游动物群落之 间关系的研究成果。

\section{1 方法}

\section{1 采样区域和方法}

湾外水域取杭州湾湾口正东方向的嵊泗岛海 域, 即 $122.10^{\circ}-122.58^{\circ} \mathrm{E}, 30.54^{\circ}-30.93^{\circ} \mathrm{N}$ 海域。湾 内水域分别取杭州湾北岸东侧海域 (121.6 $7^{\circ}$ $\left.121.87^{\circ} \mathrm{E}, 30.68^{\circ}-30.83^{\circ} \mathrm{N}\right)$ 、南岸东侧海域 $\left(121.60^{\circ}-121.85^{\circ} \mathrm{E}, 29.95^{\circ}-30.24^{\circ} \mathrm{N}\right)$ 、北岸西侧海 域 $\left(121.31^{\circ}-121.56^{\circ} \mathrm{E}, 30.58^{\circ}-30.77^{\circ} \mathrm{N}\right)$, 除了杭州 湾北岸东侧海域设13个站位以外(图1)，其他所有比 较区域各设 12 个站位，4个水域的调查季节分别为 2012年、2009年、2011年和2012年的秋季。浮游动 物样品采用浅水I型浮游生物网( 口径50 cm、篮绢 CQ14、孔径0.505 mm), 自海底至海面垂直拖曳获 得。样品采集的方法及处理等均按《海洋调查规范 一海洋生物调查》(GB/T 12763.6-2007)进行。所 获得的样品经 $5 \%$ 中性福尔马林溶液固定后带回实 

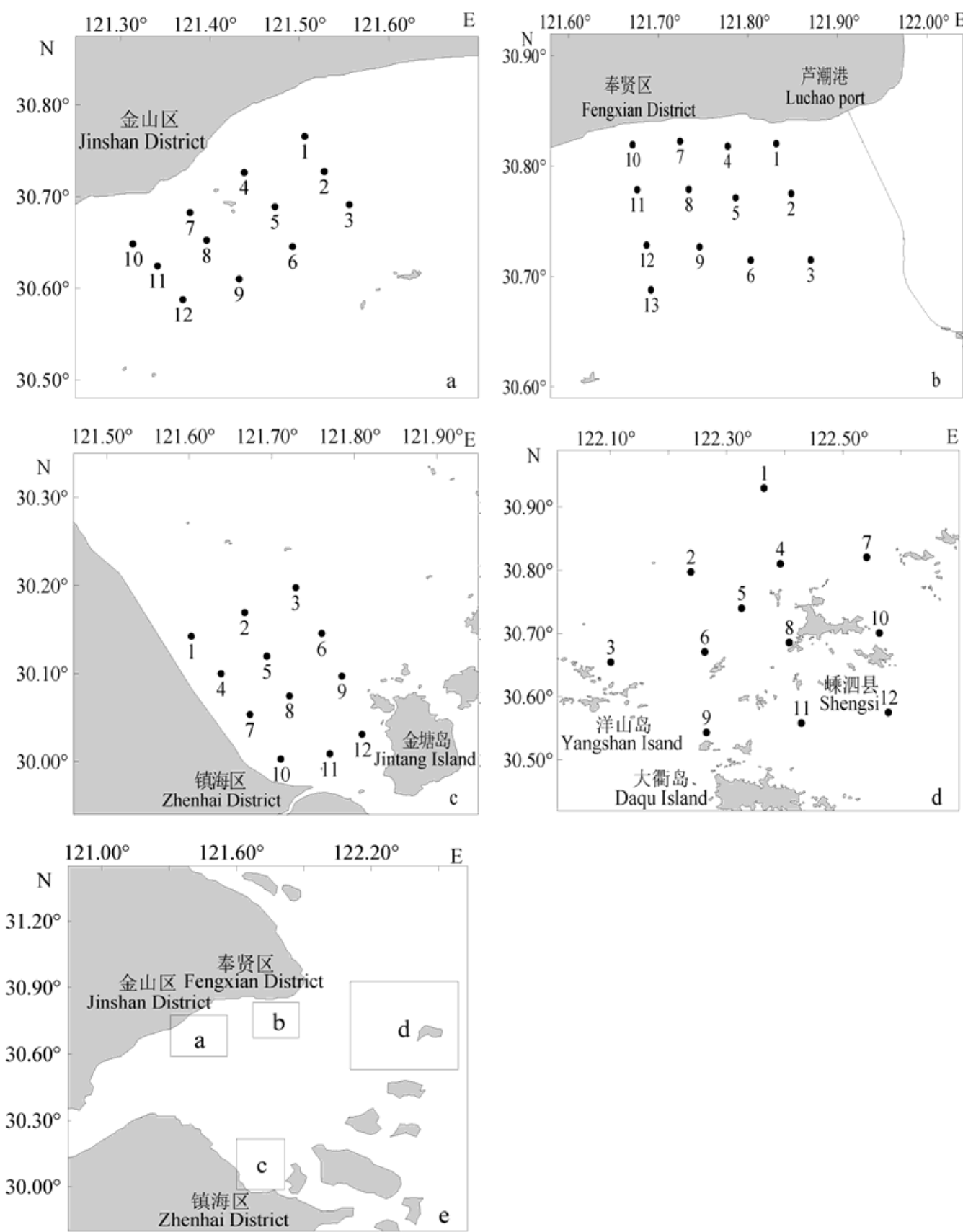

图1 杭州湾内外海域浮游动物采样站位图。 $\mathrm{a}$ : 湾内北岸西侧海域; $\mathbf{b}$ : 湾内北岸东侧海域; $\mathbf{c}$ : 湾内南岸东侧海域; $\mathbf{d}$ : 湾外海 域; e: 不同海域调查站位分布图。

Fig. 1 Sampling stations of zooplankton inside and outside the Hangzhou Bay. a, The west area of north Hangzhou Bay; b, The east area of north Hangzhou Bay; c, The east area of south Hangzhou Bay; d, The sea area outside the Bay; e, Sampling stations in the different parts.

验室进行分类鉴定和统计。并按个体计数法在体视 显微镜下计数。个体丰度单位为ind. $/ \mathrm{m}^{3}$ 。盐度用盐 度测定仪测量。

\section{2 数据处理}

4 个水域的站位依次标记为湾外海域(OA1-
12)、湾内南岸东侧海域(ES1-12)、湾内北岸东侧海 域(EN1-13)和湾内北岸西侧海域(WN1-12)。用 Primer 5.0软件(Clarke \& Green, 1993; Clarke \& Warwick, 1994; Brazner \& Beals, 1997) 建立 Bray-Curtis相似性距离矩阵, 将站位的丰度值进行 
开4次方根转换, 以平衡优势种和非优势种在群落 中的作用, 然后在此基础上分别进行聚类分析和非 线性多维标度排序分析 (NMDS)。以胁强系数 (stress) 来衡量NMDS 分析结果的好坏, 一般认为, 当stress $<0.2$ 时, 可用NMDS的二维点图表示, 其图 形有一定的解释意义; stress $<0.1$ 时, 可以认为是一 个好的排序; stress $<0.05$ 时, 具有很好的代表性; 在 $0.1<$ stress $<0.2$ 的情况下, NMDS分析的结果与 等级聚类分析的结果可以相互对照, 这样得出的分 析结论更具有实际生态学意义(Clarke \& Warwick, 1994)。

用相似性检验(ANOSIM) 非参数多元分析方法 (Clarke \& Green, 1993)检验两个群落之间是否具有 显著性差异。其具体方法是利用前面Bray-Curtis相 似性系数, 求出各相似性系数对应的秩, 以秩来表 示不同站位间的相似程度。组内站位和组间站位秩 的均值间的差异用 $R$ 值表示, $R$ 值的范围在 -1 与 1 之 间(通常在0-1间), 当 $R$ 值接近于 1 时, 表明组内各站 位的相似性明显高于组间各站位的相似性; 当 $R$ 值 接近于 0 时, 表示组内各站位与组间各站位具有基 本相同的相似性程度(Clarke \& Green, 1993)。

累积优势度是物种丰度占总丰度百分数的累 加值, 通过对各种浮游动物的丰度由大到小排序, 生成累积优势度曲线(dominance curve, $K$-dominance), 该曲线能够较直观地表示群落的物种均匀度 和丰度百分比(Clarke \& Green, 1993)。

本文优势种采用如下公式计算: $Y=\left(n_{i} / N\right) \times f_{i}$ 。 式中: $n_{i}$ 为第 $i$ 种类在各站出现的总丰度 $\left(\right.$ ind. $\left./ \mathrm{m}^{3}\right) ; N$ 为所有物种在各站出现的总丰度 (ind. $/ \mathrm{m}^{3}$ ); $f_{i}$ 为第 $i$ 种 类在各站出现的频率。定义 $Y \geq 0.02$ 的种为优势种 (徐兆礼和陈亚翟, 1989)。

采用Shannon-Wiener多样性指数 $\left(H^{\prime}\right)$ 计算群落 多样性, 公式 $H^{\prime}=-\sum P_{i} \ln P_{i}$ 。 其中, $p_{i}$ 为种 $i$ 的个体占 群落中总个体的比例, $S$ 为样品中的种类数 (Shannon, 1948)。用SPSS 16.0软件对盐度和多样性 指数 $\left(H^{\prime}\right)$ 作方差分析。

\section{2 结果}

\section{1 杭州湾内外海域盐度特征比较}

从盐度均值来看, 杭州湾湾外海域的盐度最 高, 为 23.8 , 而湾内北岸西侧海域的盐度最低, 仅 有 7.9 , 两个海域的差值最大, 超过 15.0 。湾外海域

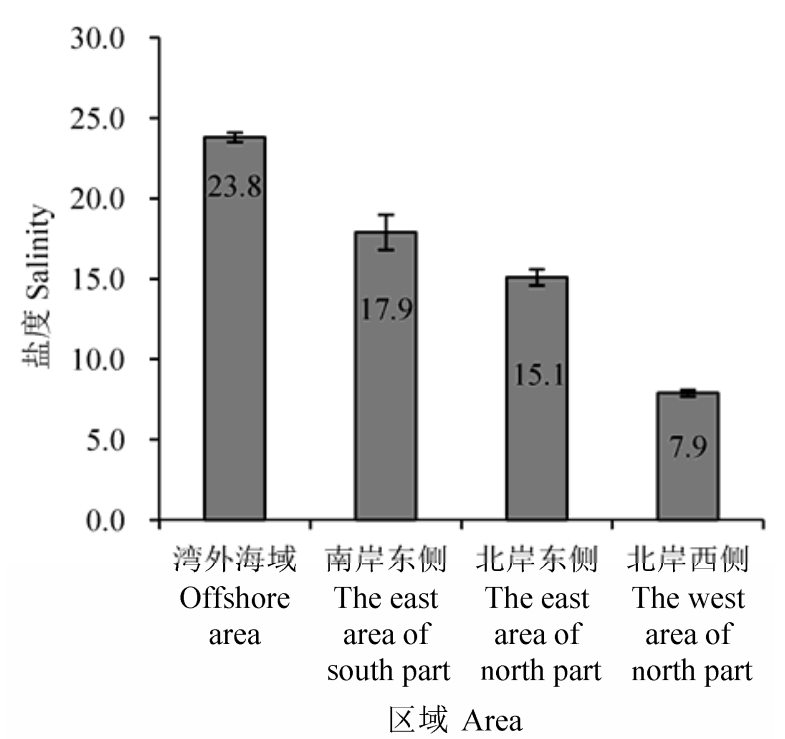

图2 杭州湾内外海域秋季盐度的比较

Fig. 2 Comparison of salinity inside and outside the Hangzhou Bay in autumn

与湾内南岸东侧(17.9)和北岸东侧海域(15.1)的盐度 差值均在 10.0 以内; 各水域内盐度变化不大(图 2 )。 对盐度作方差分析, 结果显示湾外海域与湾内 3 个 海域均有极显著差异 $(P<0.01)$, 湾内 3 个海域之间 也有极显著差异 $(P<0.01)$ 。

\section{2 杭州湾内外海域浮游动物的聚类、排序分析}

聚类分析结果显示(图3), 杭州湾内外海域浮游 动物群落差异明显。在 $25 \%$ 的相似性水平上, 可将 各调查站位分为湾外与南岸东侧的相对高盐群落 (群落I和II)和湾内北岸东侧与西侧的低盐群落(群 落III和IV)。在 $35 \%$ 的相似性水平上, 靠近湾外的相 对高盐群落又可进一步分为湾外海域群落(群落I) 和湾内南岸东侧海域的群落(群落II)。相似性分析显 示, 群落I与群落II有较大的差异 $(R=0.796)$ (表 1$)$ 。 在 $45 \%$ 的相似性水平上, 位于湾内的低盐群落可进 一步分为湾内北岸东侧海域的群落(群落III)和北岸 西侧海域的群落(群落IV)。而由表1可知, 湾外的群 落I与湾内的群落III和群落IV均具有极为明显的差 异(分别为 $R=0.979$ 和 $R=0.992$ ), 远远高于群落 $\mathrm{I} 与$ 群落II的差异。

NMDS排序的胁强系数为 0.15 (图4), 小于 0.2 , 说明NMDS图有一定的可信度。由图4可以看出, 群 落I与群落IV的距离最远, 群落组成差异最大。而群 落II与群落I的部分站位距离相对较近, 因而群落组 


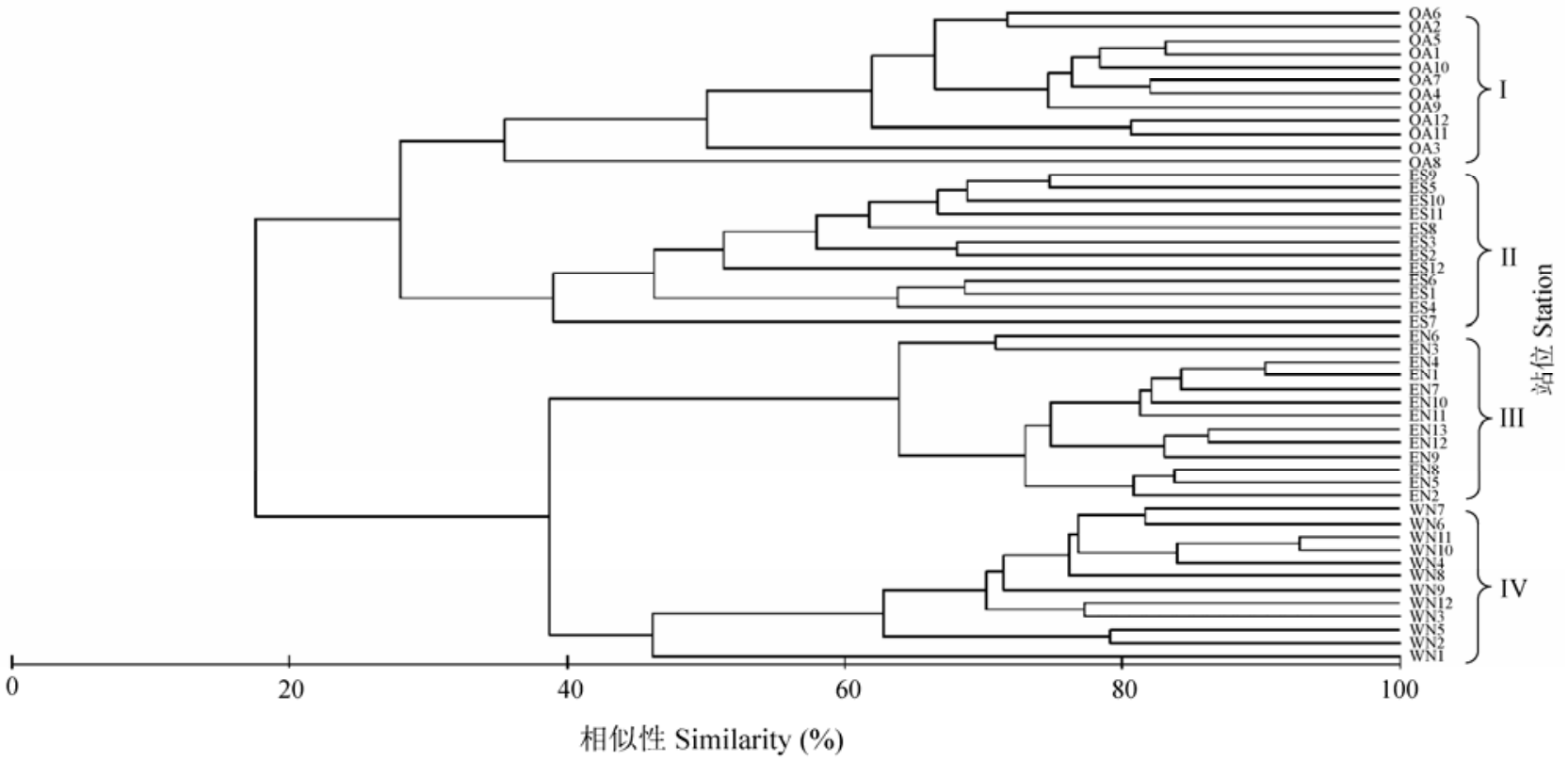

图3 杭州湾内外海域秋季浮游动物群落Bray-Curtis聚类图。I: 湾外海域浮游动物群落, II: 湾内南岸东侧海域浮游动物群 落, III: 湾内北岸东侧海域浮游动物群落, IV: 湾内北岸西侧海域浮游动物群落. 下同.

Fig. 3 Bray-Curtis cluster of zooplankton community structure inside and outside the Hangzhou Bay in autumn. I: Community in the offshore area, II: Community in the east area of south part, III: Community in the east area of north part, IV: Community in the west area of north part. The same below.

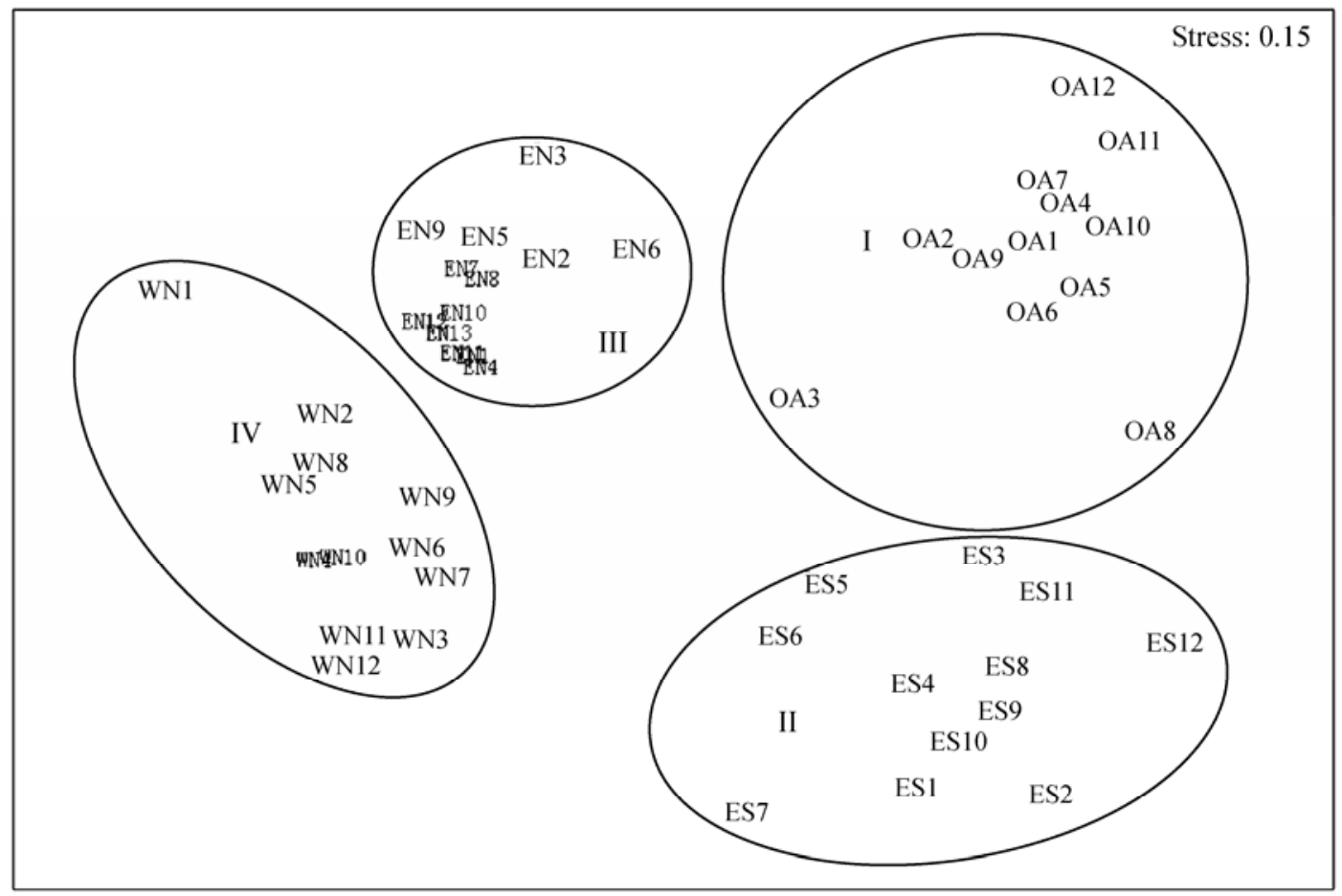

图4 杭州湾内外海域秋季各站位浮游动物群落的非线性多维标度排序分析(NMDS)

Fig. 4 Non-metric multidimensional scaling analysis of zooplankton community at each sampling station inside and outside the Hangzhou Bay in autumn 
表1 秋季杭州湾内外海域基于浮游动物丰度的群落相似性 检验

Table 1 Results of one-way analysis of similarities (ANOSIM) for zooplankton communities inside and outside the Hangzhou Bay in autumn

\begin{tabular}{lll}
\hline $\begin{array}{l}\text { 区域 } \\
\text { Area }\end{array}$ & $P$ & $\begin{array}{l}\text { ANOSIM } \\
R\end{array}$ \\
\hline $\begin{array}{l}\text { 湾外海域与湾内南岸东侧 } \\
\begin{array}{l}\text { Offshore area vs The east area of south part } \\
\text { 湾外海域与湾内北岸东侧 }\end{array}\end{array}$ & 0.001 & 0.796 \\
$\begin{array}{l}\text { Offshore area vs The east area of north part } \\
\text { 湾外海域与湾内北岸西侧 }\end{array}$ & 0.001 & 0.979 \\
$\begin{array}{l}\text { Offshore area vs The west area of north part } \\
P:\end{array}$ & 0.001 & 0.992 \\
\hline
\end{tabular}

$P:$ 表示显著性; $R$ : 表示检验值.

$P$, represent significance; $R$, represent test value.

成上与其他群落相比更为相似; 群落III与群落I的 个别站位距离相对较近, 群落组成有相似之处, 但 与群落II相比, 差异更加明显。图3和图4的对照结果 进一步证明了杭州湾内外海域的浮游动物群落之 间具有较明显的差异。

\section{3 杭州湾内外海域浮游动物的累积优势度曲线}

由图5可以看出, 湾外的群落I与湾内的群落III 累积优势度曲线的上升趋势均比较平缓, 但群落I 的最高单种所占总丰度的百分比仅为 $19.12 \%$, 低于 群落III的 $41.52 \%$, 浮游动物优势种不突出, 群落物 种多样性较高。湾内的群落II和群落IV的浮游动物 累积优势度曲线上升很快, 最高单种占总丰度的百 分比分别为 $65.32 \%$ 和 $66.96 \%$, 均远高于群落I, 而 物种多样性却较低。在物种排序 $30 \%$ 之后, 湾内外 海域的 4 个群落优势度曲线上升趋势基本一致。

\section{4 杭州湾内外海域浮游动物生态类群丰度和种} 类组成的比较

由表2和图6可知, 湾外的群落I中的近海种和 沿岸低盐种分别占浮游动物总丰度的 $53.01 \%$ 和 36.84\%。其中，近海种中华假磷虾(Pseudeuphausia sinica $)$ 的丰度为 29.3 ind. $/ \mathrm{m}^{3}$, 比湾内的群落II中 $(0.1$ ind. $/ \mathrm{m}^{3}$ ) 高很多, 沿岸低盐种背针胸刺水蚤 (Centropages dorsispinatus) 的丰度为 $26.9 \mathrm{ind} . \mathrm{m}^{3}$, 也比湾内的群落III中 $\left(0.2\right.$ ind. $\left./ \mathrm{m}^{3}\right)$ 高很多。同时, 还 出现了较多的外海种类, 如亚强真哲水蚤 (Eucalanus subcrassus)、精致真刺水蚤(Euchaeta concinna) 和肥胖箭虫(Sagitta enflata)等。湾外的群 落I中的外海种占总种类数的比例高达 $41.94 \%$, 远 高于湾内其他海域。近海种种类数的占比略低, 为 $32.26 \%$; 沿岸低盐种次之, 为 $22.58 \%$ (图7)。

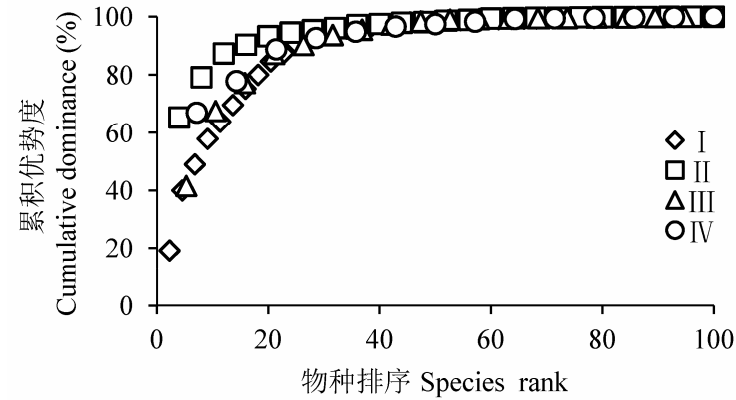

图5 杭州湾内外海域秋季浮游动物丰度累积优势度曲线

Fig. $5 K$-dominance curves by abundance inside and outside the Hangzhou Bay in autumn

与湾外的群落I相比, 湾内的群落II中的沿岸低 盐种所占比例较多，占总丰度的 $80.97 \%$ 。其中沿岸 低盐种左突唇角水蚤(Labidocera sinilobata) 的丰度 甚至高达 $378.1 \mathrm{ind} . / \mathrm{m}^{3}$; 虽然出现了一些近海种，但 近海种占总丰度的比例只有 $18.34 \%$, 低于群落I (表 2和图6)。湾内的群落II中沿岸低盐种种类数占总种 类数的比例高达 $47.06 \%$, 高于群落I; 近海种种类 数占比为 $35.29 \%$ ，与群落I相近; 外海种种类数占 比(11.76\%)远低于群落I (图7)。

湾内的群落III中的沿岸低盐种丰度和占比远 高于湾外的群落I, 其丰度占浮游动物总丰度的 $74.61 \%$ ，真刺唇角水蚤 (Labidocera euchaeta) 丰度 高达 41.1 ind. $/ \mathrm{m}^{3}$, 高于群落I $\left(4.0\right.$ ind. $\left./ \mathrm{m}^{3}\right)$ 。另一方 面, 群落III还出现了较多的河口半咸水种, 占浮游 动物总丰度的 $20.68 \%$, 如火腿许水蚤 (Schmackeria poplesia $)$ 的丰度值为 9.9 ind. $/ \mathrm{m}^{3}$, 但在湾外的群落I 中却没有出现(表2和图6)。湾内的群落III中沿岸低 盐种和近海种种类数占总种类数的比例分别为 $35.71 \%$ 和 $42.86 \%$, 均略高于湾外的群落 I; 河口半 咸水种种类数占比为 $21.43 \%$, 远高于群落I; 但未 出现外海种(图7)。

湾内的群落IV的生态类群种类组成中, 河口半 咸水种占浮游动物总丰度的比例最高，达 $79.84 \%$, 远高于湾外的群落I。其中，虫肢歪水蚤(Tortanus vermiculus $)$ 的丰度达 $32.1 \mathrm{ind} . / \mathrm{m}^{3}$, 在湾外的群落I中 仅有 0.1 ind. $/ \mathrm{m}^{3}$; 群落IV还出现了一些沿岸低盐种, 占浮游动物总丰度的 $18.64 \%$, 低于群落I, 出现的种 类如长额刺糠虾(Acanthomysis longirostris)、双刺唇 角水蚤 (Labidocera bipinnata) 和太平洋纺锤水蚤 (Acartia pacifica)等的丰度值均不高(表2和图6)。湾 
表2 杭州湾内外海域秋季浮游动物生态类群种类和丰度的组成

Table 2 Eco-group species composition and abundance of zooplankton inside and outside the Hangzhou Bay in autumn

\begin{tabular}{|c|c|c|c|c|c|c|}
\hline & \multirow{2}{*}{ 种名 Species } & \multicolumn{4}{|c|}{ 平均丰度 Mean abundance (ind. $/ \mathrm{m}^{3}$ ) } & \multirow{2}{*}{$\begin{array}{l}\text { 生态类群 } \\
\text { Eco-group }\end{array}$} \\
\hline & & $\mathrm{I}$ & II & III & IV & \\
\hline 中华哲水蚤 & Calanus sinicus & 12.5 & & 0.1 & 0.1 & $\square$ \\
\hline 火腿许水虫 & Schmackeria poplesia & & & 9.9 & 0.9 & - \\
\hline 双刺唇角水蚤 & Labidocera bipinnata & & 0.8 & & 0.1 & $\square$ \\
\hline 真刺唇角水虫 & Labidocera euchaeta & 4.0 & 47.4 & 41.1 & 0.1 & $\square$ \\
\hline 左突唇角水蚤 & Labidocera sinilobata & & 378.1 & & 1.9 & $\square$ \\
\hline 太平洋纺锤水蚤 & Acartia pacifica & & & 1.8 & 0.5 & $\square$ \\
\hline 虫肢丕水蚤 & Tortanus vermiculus & 0.1 & 2.8 & 9.6 & 32.1 & - \\
\hline 针刺拟哲水蚤 & Paracalanus aculeatus & 0.8 & 0.3 & 25.7 & & $\square$ \\
\hline 背针胸刺水蚤 & Centropages dorsispinatus & 26.9 & 1.5 & 0.2 & & $\square$ \\
\hline 中华胸刺水蚤 & Centropages sinensis & & & 3.1 & & $\square$ \\
\hline 中华华哲水蚤 & Sinocalanus sinensis & & & 0.1 & & - \\
\hline 亚强真哲水蚤 & Eucalanus subcrassus & 8.4 & 0.1 & & & $※$ \\
\hline 刺尾角水蚤 & Pontella spinicauda & & 17.6 & & & $\square$ \\
\hline 刺尾纺锤水蚤 & Acartia spinicauda & 0.2 & 2.2 & & & $\square$ \\
\hline 微刺哲水蚤 & Canthocalanus pauper & 0.5 & & & & $※$ \\
\hline 圆唇角水蚤 & Labidocera rotunda & 6.7 & & & & $\square$ \\
\hline 平滑真刺水蚤 & Euchaeta plana & 6.5 & & & & $\square$ \\
\hline 精致真刺水蚤 & Euchaeta concinna & 2.2 & & & & $※$ \\
\hline 尖刺唇角水蚤 & Labidocera acuta & 0.4 & & & & $\square$ \\
\hline 普通波水蚤 & Undinula vulgaris & 0.1 & & & & $※$ \\
\hline 瘦尾胸刺水蚤 & Centropages tenuiremis & 0.1 & & & & $\square$ \\
\hline 黑点叶水蚤 & Sapphirina nigromaculata & 0.1 & & & & $※$ \\
\hline 伯氏平头水蚤 & Candacia bradyi & 0.1 & & & & $※$ \\
\hline 小哲水蚤 & Nannocalanus minor & 0.1 & & & & $※$ \\
\hline 漂浮囊糠虾 & Gastrosaccus pelagicus & & & 0.1 & 0.4 & $\square$ \\
\hline 长额刺糠虾 & Acanthomysis longirostris & 8.2 & 5.9 & 1.8 & 5.2 & $\square$ \\
\hline 短额刺糠虾 & Acanthomysis brevirostris & 7.9 & 7.2 & & & $\square$ \\
\hline 漂浮小井伊糠虾 & Iiella pelagicus & 1.4 & 2.5 & & & $\square$ \\
\hline 中华假磷虾 & Pseudeuphausia sinica & 29.3 & 0.1 & & & $\square$ \\
\hline 日本毛虾 & Acetes japonicus & 0.1 & 0.6 & & & $\square$ \\
\hline 中型莹虾 & Lucifer intermedius & 0.4 & 0.3 & & & $※$ \\
\hline 细螯虾 & Leptochela gracilis & & 0.1 & & & $\square$ \\
\hline 细长涟虫 & Iphinoe tenera & & & 1.0 & 0.1 & $\square$ \\
\hline 三叶针尾涟虫 & Diastylis tricincta & 0.1 & & & & $\square$ \\
\hline 百陶箭虫 & Sagitta bedoti & 12.7 & 80.2 & 0.1 & 0.1 & $\square$ \\
\hline 海龙箭虫 & Sagitta nagae & 0.1 & & 0.1 & & $\square$ \\
\hline 肥胖箭虫 & Sagitta enflata & 1.1 & & & & $※$ \\
\hline 细尖小涂氏蜮 & Tullbergella cuspidata & 0.3 & & & & $※$ \\
\hline 尖笔帽螺 & Creseis acicula & 0.1 & & & & $※$ \\
\hline 明螺 & Atlanta peroni & 0.0 & & & & $※$ \\
\hline 齿形海萤 & Cypridina dentata & 0.0 & & & & $※$ \\
\hline
\end{tabular}

घ: 河口半咸水种; $\square$ : 沿岸低盐种; 口: 近海种; ※：外海种

п: Estuarine brackish-water species; $\square$ : Nearshore low-salinity species; $\square$ : Nearshore species; ※: Offshore species

内的群落IV中河口半咸水种占总种类数的比例为

$18.18 \%$ ，远高于群落I; 沿岸低盐种和近海种种类 数分别为 $45.45 \%$ 和 $36.36 \%$, 均略高于湾外的群落I;
但未出现外海种(图7)。

\section{5 杭州湾内外海域浮游动物优势种的比较}

从图 8 和表 2 可以看出, 湾外的群落I的优势种 


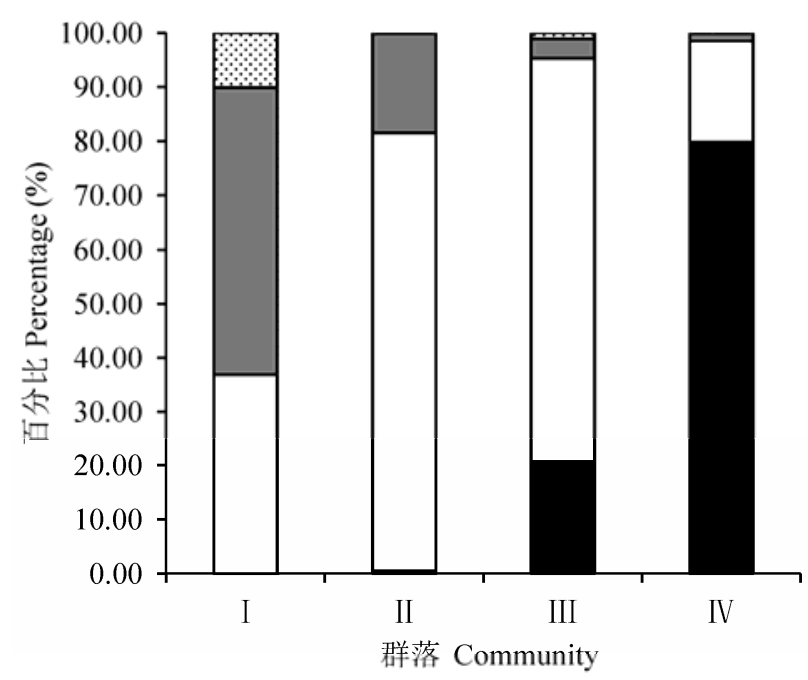

巴外海种 Offshore species

口近海种 Nearshore species

口沿岸低盐种 Nearshore lowsalinity species

曰河口半咸水种 Estuarine brackish-water species

图6 秋季杭州湾内外不同群落浮游动物生态类群丰度比例 的变化

Fig. 6 The variation of eco-group abundance of zooplankton communities inside and outside the Hangzhou Bay in autumn

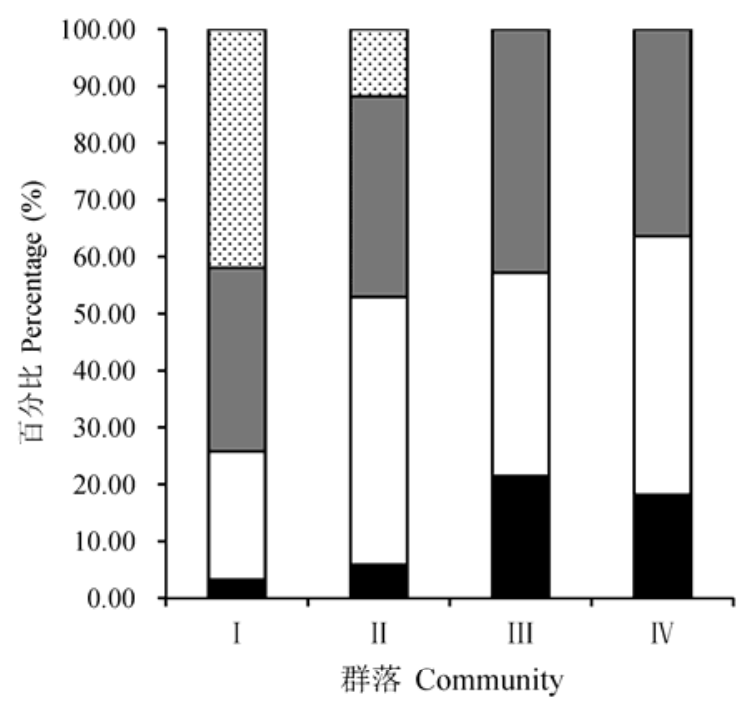

曰外海种 Offshore species

口近海种 Nearshore species

口沿岸低盐种 Nearshore lowsalinity species

口河口半咸水种 Estuarine brackish-water species

图7 秋季杭州湾内外不同群落浮游动物生态类群种类数比 例的变化

Fig. 7 The variation of eco-group species numbers of zooplankton communities inside and outside the Hangzhou Bay in autumn

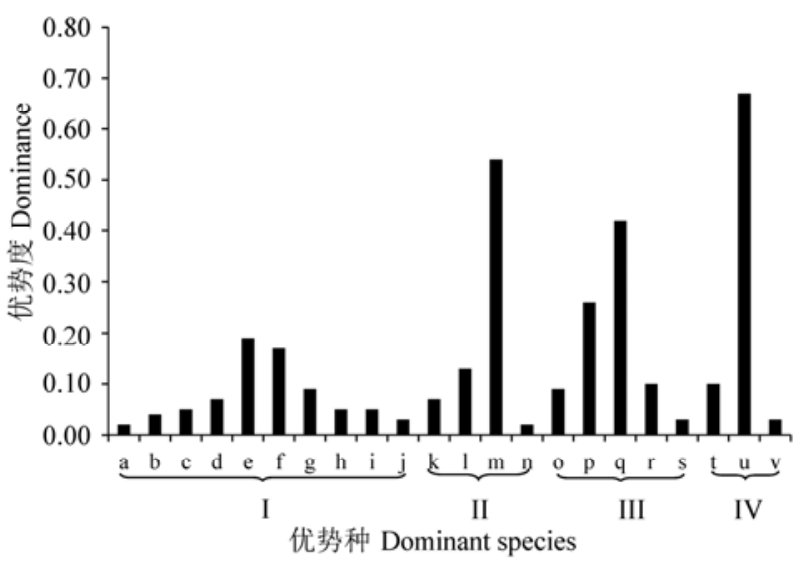

图8 秋季杭州湾内外不同群落浮游动物优势种优势度的变 化。a, k, q: 真刺唇角水蚤; b: 圆唇角水蚤; c: 短额刺糠虾; $\mathrm{d}$ : 中华哲水蚤; e: 背针胸刺水蚤; $\mathrm{f}$ : 中华假磷虾; $\mathrm{g}, \mathrm{l}$ : 百陶箭 虫; $h$ : 亚强真哲水蚤; $i, t:$ 长额刺糠虾; $j$ : 平滑真刺水蚤; $m$, $\mathrm{v}$ : 左突唇角水蚤; $\mathrm{n}$ : 刺尾角水蚤; $\mathrm{o}$ : 火腿许水蚤; $\mathrm{p}$ : 针刺 拟哲水蚤; $\mathrm{r}, \mathrm{u}$ : 虫肢歪水蚤; $\mathrm{s}$ : 中华胸刺水蚤.

Fig. 8 The variation of dominance of dominant species of zooplankton inside and outside the Hangzhou Bay in autumn. a, k, q: Labidocera euchaeta; b: Labidocera rotunda; c: Acanthomysis brevirostris; d: Calanus sinicus; e: Centropages dorsispinatus; f: Pseudeuphausia sinica; g, 1: Sagitta bedoti; h: Eucalanus subcrassus; i, t: Acanthomysis longirostris; j: Euchaeta plana; m, v: Labidocera sinilobata; n: Pontella spinicauda; o: Schmackeria poplesia; p: Paracalanus aculeatus; r, u: Tortanus vermiculus; s: Centropages sinensis.

主要有近海种中华假磷虾、百陶箭虫 (Sagitta bedoti)、中华哲水蚤(Calanus sinicus) 以及沿岸低盐 种背针胸刺水蚤和外海种亚强真哲水蚤等，各优势 种的优势度均不高, 其中, 近海种占该海域优势种 总丰度的 $55.05 \%$, 沿岸低盐种占优势种总丰度的 $38.14 \%$ ，外海种只占 $6.82 \%$ 。

与群落I相比, 湾内的群落II的优势种组成有很 大的不同，优势种为沿岸低盐种左突唇角水蚤、真 刺唇角水蚤以及近海种百陶箭虫、刺尾角水蚤 (Pontella spinicauda)。其中沿岸低盐种的平均丰度 占该海域优势种总丰度的 $81.32 \%$, 远高于群落 I; 近海种占 $18.68 \%$, 远低于群落I (图8和表2)。

湾内的群落III的优势种主要有沿岸低盐种真 刺唇角水蚤、针刺拟哲水蚤和河口半咸水种虫肢歪 水蚤、火腿许水蚤以及近海种中华胸刺水蚤。其中, 沿岸低盐种和河口半咸水种分别占优势种总丰度 的 $74.77 \%$ 和 $21.79 \%$, 均远高于群落I; 近海种只有 $3.44 \%$, 远低于群落I (图8 和表2)。

湾内的群落IV的优势种组成与群落I则有极大 
的不同，主要为河口半咸水种虫肢歪水蚤和沿岸低 盐种长额刺糠虾、左突唇角水蚤3 种, 远少于群落 $\mathrm{I}$ 。 其中, 河口半咸水种占该水域优势种总丰度的 $81.88 \%$, 以绝对优势成为最主要的类群, 远高于群 落I, 而沿岸低盐种只占 $18.12 \%$, 低于群落I (图8和 表2)。

\section{6 杭州湾内外海域浮游动物群落多样性指数 $\left(\boldsymbol{H}^{\prime}\right)$ 的水平分布及方差分析}

湾外的群落I的Shannon-Wiener多样性指数范 围为 1.74-3.85, 均值为 3.04, 为湾内外海域最高, 多样性指数总体呈现由北部向南部增加的趋势 (图9)。

湾内的群落II的Shannon-Wiener多样性指数范
围为0.61-2.64, 均值只有 1.60 , 远低于群落I, 浮游 动物的多样性指数分布趋势呈现为向东南部离岸 方向增加(图9)。

湾内的群落III的Shannon-Wiener多样性指数范 围为 1.04-2.71, 均值为 1.94 , 也低于群落 I, 多样性 指数分布表现为自东部向西部递增的趋势(图9)。

湾内的群落IV的Shannon-Wiener多样性指数范 围为 $0.87-2.81$, 均值为 1.77 , 同样低于群落I, 多样 性指数分布总体呈现为西部近岸侧较低, 离岸侧较 高, 而东部离岸侧较低, 近岸侧较高(图9)。

方差分析结果显示, 湾外海域的浮游动物群落 多样性指数与湾内 3 个海域均有极显著差异 $(P<$ $0.01)$, 而湾内各海域之间均无显著差异 $(P>0.05)$ 。
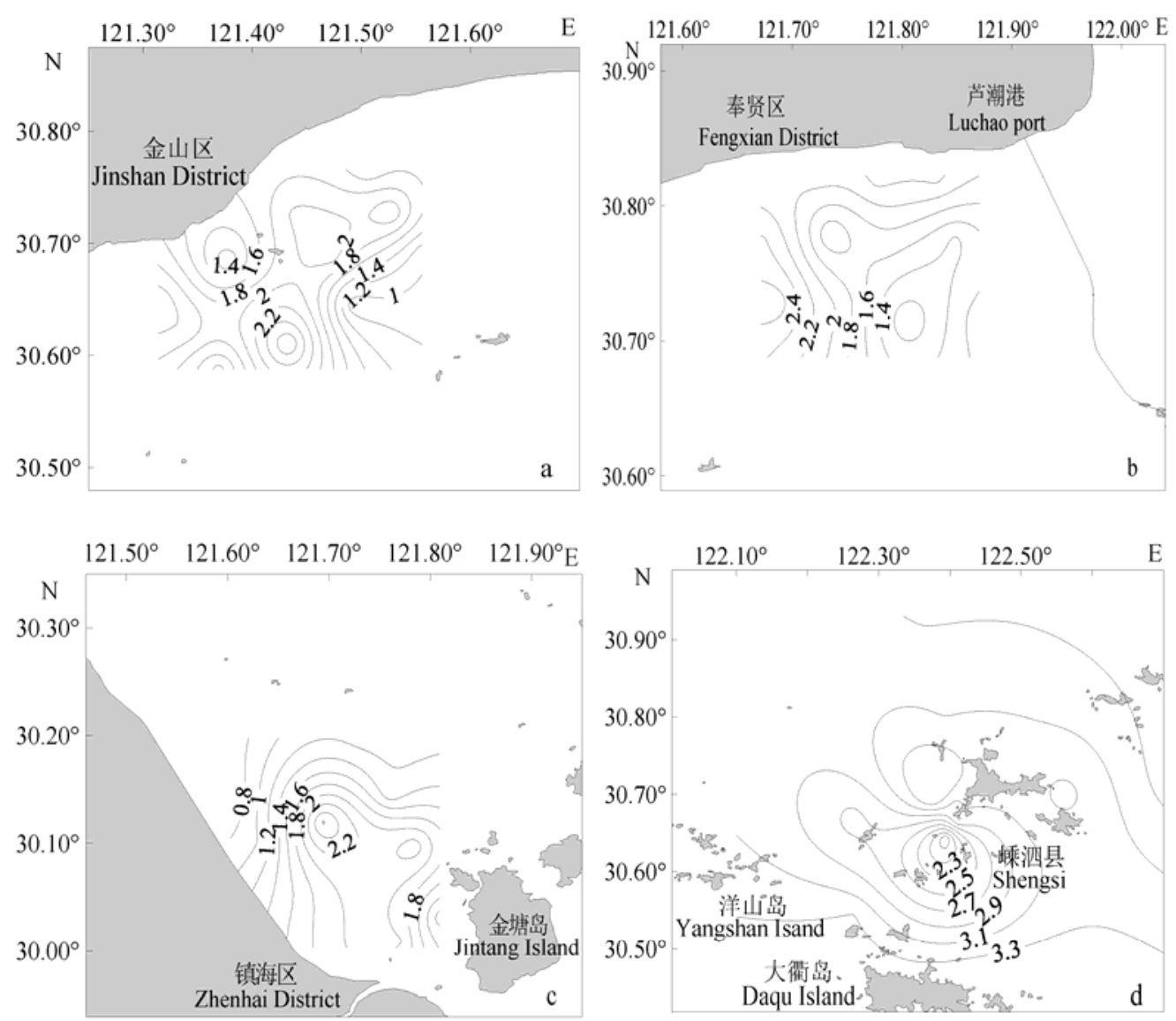

图9 杭州湾内外海域秋季浮游动物群落多样性指数 $\left(H^{\prime}\right)$ 的水平分布。a: 湾内北岸西侧海域的群落IV; b: 湾内北岸东侧海域 的群落III; c: 湾内南岸东侧海域的群落II; d: 湾外海域的群落I.

Fig. 9 Horizontal distribution of Shannon-Wiener diversity index of zooplankton communities inside and outside the Hangzhou Bay in autumn. a, Community IV in the west area of north part; b, Community III in the east area of north part; c, Community II in the east area of south part; d, Community I in the offshore area. 


\section{3 讨论}

\section{1 杭州湾内外不同海域浮游动物群落的划分}

依据聚类分析、非线性多维标度排序分析和群 落相似性分析的研究结果(图3, 图4和表1), 杭州湾 湾外浮游动物群落 $\mathrm{I}$ 与湾内 3 个群落有非常显著的差 别, 尤其是与湾内北岸各浮游动物群落的差异非常 显著。而湾外的群落I与湾内南岸东侧的群落II可以 划分为一大类, 这是因为, 这两个水域受径流影响 偏弱, 受外海水影响明显。其中, 群落II附近虽然没 有较强的淡水径流, 但与外海水团之间由于受到舟 山岛屿的阻隔, 影响了外海水团的入侵, 因此, 无 论是从丰度还是种类组成上, 外海种和近海种的数 量均明显低于杭州湾湾外浮游动物群落I的数量。显 示出地形阻隔对浮游动物群落有重要的影响(刘镇 盛等, 2005; 徐佳奕等, 2014)。

由于受到淡水径流的影响, 杭州湾北岸的浮游 动物群落都显示出明显的咸淡水交界生态适应属 性, 因而可以划分为同一大类, 但是这两个群落之 间也有差异。北岸东侧的群落III接近外海, 岛屿对 外海水阻隔程度虽然较弱, 但有强大的长江径流从 南支下泄影响这一海域，依靠淡水水团与外海所形 成的阻隔, 形成了一个既区别于杭州湾湾外浮游动 物群落I, 又区别于北岸西侧的群落IV的浮游动物 群落。由于接近钱塘江口, 与外海相距较远, 在 4 个 浮游动物群落中, 群落IV显示出一个典型的河口浮 游动物群落特征(徐兆礼等, 1999; 高原等, 2008)。

\section{2 从生态类群丰度组成的差异看浮游动物对不 同环境的适应}

由图3和图4可见, 杭州湾湾外海域的群落I与 湾内南岸东侧的群落II、北岸东侧的群落III、北岸 西侧的群落IV相比, 均具有极显著差异(表1), 而这 种群落结构的差异主要表现在不同生态类群丰度 的差异上。

研究结果显示, 湾外海域的浮游动物群落I以 近海种为主(占总丰度的 53.01\%) (表2和图6), 此外 还出现较多的外海种, 这是湾外海域浮游动物生态 类群最重要的特征。相比之下, 湾内南岸东侧群落 II 以沿岸低盐种为最主要的种类 $(80.97 \%)$, 还有较 多的近海种出现; 湾内北岸东侧群落III占主导的虽 然仍是沿岸低盐种 $(74.61 \%)$, 但是出现了较多湾外 海域没有出现的河口半咸水种 $(20.68 \%)$; 湾内北岸
西侧群落IV与湾外群落I由于在地理位置上相距最 远，近钱塘江口，以河口半咸水种为主 $(79.84 \%)$, 而沿岸低盐种次之(图6)。湾内外浮游动物生态类群 丰度组成的差异，反映了不同生态类群浮游动物对 不同环境的适应。

在湾外海域, 近海种丰度最高, 显示出湾外海 域具有适合近海种栖息的环境。依据 $\mathrm{Xu}$ 和 $\mathrm{Gao}$ (2011)、Zhang和Xu (2012)、沈国英和施并章(2002) 等的研究, 近海浮游动物适应盐度在20-32之间。显 然, 湾外海域的盐度相对湾内其他 3 个海域较高 (23.8) (图2), 而盐度又影响到浮游动物的群落结构 和种类组成(陈洪举和刘光兴, 2009), 因而, 湾外海 域在群落丰度组成上以盐度适应性偏高的近海种 占优, 甚至还出现了一定数量的外海种。在湾内南 岸东侧和北岸东侧, 则出现了大量的沿岸低盐种, 说明这些海域是沿岸低盐种适宜栖息的海域。此外, 在北岸还出现了较多数量的河口半咸水种, 尤其是 在北岸西侧, 由于离外海距离较远, 又受到钱塘江 冲淡水影响, 水体的盐度最低, 仅为7.9 (图2), 是适 宜河口半咸水种栖息的水域。由此可见，径流通过 盐度梯度对浮游动物带来的影响, 叠加外海水团的 影响, 是造成不同海域群落中不同生态类群数量差 异的主要原因，也印证了不同生态类群浮游动物对 不同海洋环境的适应(高倩等, 2008; 田丰歌和徐兆 礼, 2012; 徐佳奕等, 2014)。

\section{3 从生态类群种类组成的差异看不同水团对海 洋环境的影响}

径流通过盐度梯度, 叠加外海水团对浮游动物 带来的影响，除了显示出不同生态类群对不同海洋 环境的适应以外，还显示出水团对某一海域的入侵 和影响, 主要通过不同生态类群种类数、占总种类 数比例和参考种的丰度组成来进行研究。

虽然在湾外，近海种丰度远大于外海种，但在 种类数上, 群落I表现为外海种(13种)种类数高于近 海种(10种)(表2)，因而种类组成上，显示出更加强 烈的外海特征。由于湾外海域与舟山群岛外海域之 间基本上没有阻挡，它们之间在水体上是相通的。 在台湾暖流近海支(翁学传和王从敏，1985; 潘玉球 等，1985)，黑潮次表层水在近海涌升的海流背景下 (Zhang et al, 2012; Li et al, 2014; 赵瑞祥和刘志亮, 2014), 大量的外海种进入湾外海域。其中, 不乏一 些暖流水团指示种，例如精致真刺水蚤(徐兆礼等, 
2003a)、肥胖箭虫(李云等，2009)、普通波水蚤 (Undinula vulgaris)(徐兆礼, 2006)和小哲水蚤 (Nannocalanus minor) 等, 这些种只在湾外海域出 现。浮游动物都具有随波逐流的扩散特性(郑重等, 1984), 杭州湾湾外海域出现了如此众多的外海种, 由此推断，这一海域受到了外海暖流水团的影响。 而暖流带来丰富的外海种类, 是这一海域外海种种 类数多于近海种的原因。但是, 这一水域同样也受 到了来自长江口冲淡水的影响。研究表明, 湾外海 域平均盐度为 23.8 , 属于近海海洋环境特征, 对大 多数外海种而言, 并不是最适宜的栖息环境(徐兆 礼, 2007; Xu \& Gao, 2011; Zhang \& Xu, 2012)。这是 外海种虽然占多数, 但丰度占比很少的原因。

在湾内东侧, 南岸(群落II)和北岸(群落III)有所 不同, 虽然它们在生态类群丰度组成上均以沿岸低 盐种占绝对优势, 丰度占比分别高达 $80.97 \%$ 和 $74.61 \%$, 但群落II的种类组成有别于群落III。一方 面表现为: 群落II中高盐度适应种类的种类数占比 高于群落III。例如, 群落II中近海种占总种类数的比 例为 $35.29 \%$, 外海种占 $11.76 \%$, 合计 $47.05 \%$, 高于 群落III仅出现近海种的比例(42.86\%) (图7), 这一结 果显示出群落II更多地受到外海水的影响。另一方 面表现为群落III出现了河口半咸水种(占总种类数 的 $21.43 \%$ ), 而群落II几乎没有出现(图7), 显示出群 落III受到咸淡水水团的影响。

湾内北岸西侧群落IV的种类组成与湾外海域 群落I的差异最大, 出现了较多的河口半咸水种, 占 总种类数的比例(18.18\%)远高于群落I (图7)。其中, 具有代表性的河口半咸水种虫肢歪水蚤出现的数 量最多, 黄备等(2012)对这一海域春季的研究结果 也显示出虫肢歪水蚤的数量占比很高。说明北岸西 侧受冲淡水的影响比较显著, 从而与群落I形成最 明显的反差。

杭州湾内外海域浮游动物群落的种类组成差 异格局总体表现在: 湾外海域种类组成更多地显示 出暖流和冲淡水混合的影响, 湾内南北岸则总体上 显示出以盐度适应性偏低的沿岸低盐种甚至盐度 适应性更低的河口半咸水种居多, 这可能与各自海 域的主导水团有关。

\section{4 杭州湾内外海域不同浮游动物群落多样性指 数 $\left(H^{\prime}\right)$ 的差异分析}

方差分析结果表明, 湾内各海域之间的浮游动
物多样性指数 $\left(H^{\prime}\right)$ 无显著差异, 但它们与湾外海域 之间均有极显著差异, 说明湾外海域环境与湾内海 域环境差异较大。何德华等(1987)和 Magurran (1988)研究发现, 累积优势度与多样性指数 $\left(H^{\prime}\right)$ 之 间有较为密切的关系，较高的优势度曲线一般对应 较低的多样性指数。而物种多样性指数作为衡量群 落规模和重要性的基础, 与种类数的多少和丰度在 种间分布的均匀度有关(徐佳奕和徐兆礼, 2013), 种 类越多, 个体数量分布越均匀, 物种的多样性指数 就越大，可以反映出所在海域的空间异质性越高 (李开枝等, 2007)。例如，高倩等(2008)研究发现，秋 季长江口北支的浮游动物多样性指数明显高于北 港水域, 而且其丰度分布也比较均匀, 最高丰度百 分比仅为 $36.6 \%$ 。

湾外海域群落I的浮游动物多样性指数 $\left(H^{\prime}\right)$ (3.04)明显高于湾内其他 3 个海域(图9), 而黄备等 (2012)研究发现春季该海域的物种多样性指数也偏 高, 说明该海域春秋季的群落结构均比较复杂。群 落I的初始累积优势度为 4 个海域最低，只达 $20 \%$ 左 右, 累积优势度曲线上升最平缓(图5), 说明丰度分 布比较均匀, 这是群落I多样性指数 $\left(H^{\prime}\right)$ 较高的原因 之一。此外, 群落I的种类组成上除了以近海种和沿 岸低盐种为主外, 还出现了大量的外海种(表2), 其 优势种种数(10种)明显多于其他三个海域, 优势种 间的优势度差异不明显(图8), 种类组成变得复杂多 样, 因而多样性指数 $\left(H^{\prime}\right)$ 较高, 其群落结构相对其 他 3 个群落来说也十分稳定。

相比于群落I, 湾内南岸东侧群落II和北岸西侧 群落IV的多样性指数 $\left(H^{\prime}\right)$ 均非常低 $(1.60,1.77)$ (图 9)。而它们的初始累积优势度则都很高 $(65.32 \%$, 66.96\%), 累积优势度曲线上升很快(图5), 但是丰 度分布却十分不均匀, 物种相对偏少, 同时分别出 现了单一高优势度的优势种左突唇角水蚤和虫肢 歪水蚤(图8), 这进一步说明了群落II和群落IV的多 样性指数 $\left(H^{\prime}\right)$ 明显低于群落I。湾内北岸东侧群落III 的多样性指数 $\left(H^{\prime}\right)$ (1.94) (图9)虽然相对湾内其他海 域的群落来说偏高, 但仍低于群落I, 原因在于其累 积优势度曲线不同于群落I, 上升较快, 且初始累积 优势度高于群落I, 丰度分布也比较不均匀; 优势种 种类(5种)虽多于湾内其他海域, 与群落I相比仍较 少, 且优势度不是很突出, 物种组成也相对简单, 反映在多样性指数上, 往往是该群落的多样性指数 
$\left(H^{\prime}\right)$ 值较低。

总之, 杭州湾内外海域群落之间浮游动物多样 性指数 $\left(H^{\prime}\right)$ 的差异与各自海域浮游动物的累积优势 度和种类组成等有关, 湾外海域浮游动物种类数较 多, 优势种数较多, 累积优势度曲线较缓, 因而群 落多样性指数 $\left(H^{\prime}\right)$ 较高, 群落结构稳定, 而湾内水 域各个群落的多样性指数 $\left(H^{\prime}\right)$ 普遍低于 2 , 群落结构 较不稳定, 折射出湾内外海域浮游动物群落结构上 具有明显的差异。

\section{5 杭州湾内外海域浮游动物群落与水团的关系}

由前面的研究结果可知, 杭州湾内外海域群落 之间, 不论从生态类群丰度、种类组成, 还是从多 样性指数上, 都存在明显的差异, 这与各自海域受 不同主导水团的影响密不可分。

潘玉球等(1997)、林丙尧和曹颖(2000)研究发 现, 东海外海水和下泄的长江冲淡水对杭州湾湾外 海域的影响较大, 这使得群落I出现了较多数量的 近海种和沿岸低盐种, 以及较多种类但丰度不高的 外海种, 群落结构变得较为复杂。而倪勇强等(2003) 研究发现, 对湾内海域影响最大的水团主要是来自 东海并向东南和向东方向传入的东海外海水, 其次 是南下的长江冲淡水和钱塘江径流, 但不同海域受 主导水团的影响不同, 导致群落组成差异很大。湾 内南岸东侧在秋季除受东海外海水影响外, 钱塘江 径流和曹娥江径流对其也有一定影响, 水体盐度相 对偏低, 出现了较多的沿岸低盐种及少量的近海种 等, 种类组成、丰度和优势度分布均不均匀, 物种 多样性较低, 丰度的分布受单一优势种影响较大, 而浮游动物的优势种又对群落特征有重要影响 (Gouveia et al, 1999; 张锦平等, 2005), 因而群落II 在群落组成上以沿岸低盐种为主。湾内北岸东侧海 域是东海外海水、长江冲淡水和钱塘江径流的水团 交汇处, 沿岸低盐种大量聚集, 以及出现较多的河 口半咸水种, 优势种相对较多, 优势度趋于均匀, 物种多样性相对偏高, 因而, 群落III形成沿岸低盐 种和河口半咸水种的混合群落。北岸西侧海域靠近 湾顶, 秋季钱塘江大量冲淡水的注入, 使得河口半 咸水种如虫肢歪水蚤等在此大量聚集繁殖, 浮游动 物的分布由单一优势种虫肢歪水蚤决定, 物种多样 性较低, 群落结构相对简单(纪焕红等, 2004), 因此, 群落IV最主要的类群为河口半咸水种。

杭州湾内外不同海域受主导水团的影响不同,
使得湾内外各自海域浮游动物群落特征有较大差 异, 群落组成特征形成由湾外海域以近海种为主向 湾内方向以沿岸低盐种为主甚至以河口半咸水种 为主的更替规律。

致谢：沈晓民老师对本文的撰写给予指导和帮助， 齐海明、徐捷、王蔚颖、田伟、孙鲁峰等帮助采集 样品, 谨致谢忱!

\section{参考文献}

Badylak S, Philps EJ (2008) Spatial and temporal distributions of zooplankton in Tampa Bay, Florida, including observations during a HAB event. Journal of Plankton Research, 30, 449-465.

Bi YM, Xu ZL, Chen H (2010) Effects of the Yangshan Deepwater Port Project on zooplankton diversity in adjacent waters of Hangzhou Bay. Chinese Journal of Ecology, 29, 933-938. (in Chinese with English abstract) [毕亚梅, 徐兆 礼, 陈华 (2010) 洋山深水港工程对附近海域浮游动物 多样性的影响. 生态学杂志, 29, 933-938.]

Brazner JC, Beals EW (1997) Patterns in fish assemblages from coastal wetland and beach habitats in Green Bay, Lake Michigan: a multivariate analysis of abiotic and biotic forcing factors. Canadian Journal of Fishery and Aquatic Sciences, 54, 1743-1761.

Chen H, Xu ZL (2010) Effects of Yangshan Project in Hangzhou Bay on distribution of zooplankton biomass in the adjacent waters. Journal of Fishery Sciences of China, 17, 1319-1326. (in Chinese with English abstract) [陈华, 徐兆 礼 (2010) 杭州湾洋山工程群对邻近水域浮游动物数量 分布的影响. 中国水产科学, 17, 1319-1326.]

Chen HJ, Liu GX (2009) Zooplankton community structure in Yangtze River Estuary and adjacent sea area in summer 2006. Journal of Beijing Normal University (Natural Science), 45, 393-398. (in Chinese with English abstract) [陈洪举, 刘光兴 (2009) 2006年夏季长江口及其邻近水 域浮游动物的群落结构. 北京师范大学学报(自然科学 版), 45, 393-398.]

Chen XQ, Yu CG, Hu HY, Zheng J, Huang B, Wang JY (2010) Distribution characteristic of zooplankton quantitative in Zhoushan Fishing Ground and its adjacent area. Acta Ecologica Sinica, 30, 1834-1844. (in Chinese with English abstract) [陈小庆, 俞存根, 胡影琰, 郑基, 黄备, 王婕妤 (2010) 舟山渔场及邻近海域浮游动物数量分布特征. 生 态学报, 30, 1834-1844.]

Clarke KR, Green RH (1993) Non-parametric multivariate analysis of changes in community structures. Australian Journal of Ecology, 18, 117-143.

Clarke KR, Warwick R (1994) Change in Marine Communities: An Approach to Statistical Analysis and Interpretation. Primer-E Ltd, Plymouth, UK. 
Gao Q, Xu ZL, Zhuang P (2008) Comparison of mesozooplankton communities in North Channel and North Branch of Yangtze River Estuary. Chinese Journal of Applied Ecology, 19, 2049-2055. (in Chinese with English abstract) [高倩, 徐兆礼, 庄平 (2008) 长江口北港和北支浮游动 物群落比较. 应用生态学报, 19, 2049-2055.]

Gao Y, Lai ZN, Wang C, Pang SX, Wei TL, Yang WL, Xie WP (2008) Distribution characteristics of zooplankton in Pearl River Estuary. Journal of Fishery Sciences of China, 15, 260-268. (in Chinese with English abstract) [高原, 赖 子尼, 王超, 庞世勋, 魏泰莉, 杨婉玲, 谢文平 (2008) 珠江口浮游动物分布特征研究. 中国水产科学, 15 , 260-268.]

Govindan K, Kasinathan R, Desai BN (1977) Biomass and composition of zooplankton in and around Gulf of Kutch. Journal of the Indian Fisheries Association, 7(1-2), 64-76.

Gouveia I, Miguel C, Chicharo MA, Marques MH, Chicharo LM (1999) Plankton of Guadiana Estuary: seasonal distribution and relation with environmental parameters: preliminary results. Revista de Biologia (Lisbon), 17(1-4), 179-192.

He DH, Yang GM, Shen WL, Liu HB (1987) An ecological study on zooplankton in coastal upwelling zone of Zhejiang. II. Species distribution and diversity. Acta Oceanologica Sinica, 9, 617-626. (in Chinese) [何德华, 杨关铭, 沈伟林, 刘红斌 (1987) 浙江沿岸上升流区浮游动物生态研究. II. 浮游动物种类分布与多样度. 海洋学报 (中文版), 9, 617-626.]

Huang B, Wang JY, Shen MF, Tang JL, Hu HY (2012) Community structure of zooplankton in the offshore water of the northern Zhejiang. Environmental Monitoring in China, 28, 64-68. (in Chinese with English abstract) [黄备, 王婕妤, 沈明富, 唐静亮, 胡影琰 (2012) 浙江北部海域春季浮游 动物的群落结构研究. 中国环境监测, 28, 64-68.]

Ji HH, Ye SF, Huang XQ (2004) Distributional characteristics of zooplankton in Jinshan-Three-Island sea area. Marine Science Bulletin, 23(5), 87-91. (in Chinese with English abstract) [纪焕红, 叶属峰, 黄秀清 (2004) 上海市金山三岛 海域浮游动物分布特征. 海洋通报, 23(5), 87-91.]

Li HM, Shi XY, Wang H, Han XR (2014) An estimation of nutrient fluxes to the East China Sea continental shelf from the Taiwan Strait and Kuroshio subsurface waters in summer. Acta Oceanologica Sinica, 33, 1-10.

Li KZ, Yin JQ, Huang LM (2007) Research advances in estuarine zooplankton ecology. Marine Sciences, 31(3), 72-75. (in Chinese) [李开枝, 尹健强, 黄良民 (2007) 河口浮游 动物生态学研究进展. 海洋科学, 31(3), 72-75.]

Li Y, Xu ZL, Gao Q (2009) Effects of global warming on Sagitta crassa and Sagitta enflata (Chaetognatha) in the Changjiang Estuary during different years. Acta Ecologica Sinica, 29, 4774-4780. (in Chinese with English abstract) [李云, 徐兆礼, 高倩 (2009) 长江口强壮箭虫和肥胖箭虫的丰 度变化对环境变暖的响应. 生态学报, 29, 4774-4780.]
Lin BY, Cao Y (2000) The analysis of tidal characteristics in the Hangzhou Bay. Estuarine and Coastal Engineering, 12(2), 16-25. (in Chinese) [林丙尧, 曹颖 (2000) 杭州湾 潮汐特性分析. 河口与海岸工程, 12(2), 16-25.]

Liu ZS, Wang CS, Zhang ZN, Cai YM, Zhang DS (2005) Seasonal dynamics and grazing rate of zooplankton in Yueqing Bay. Acta Ecologica Sinica, 25, 1853-1862. (in Chinese with English abstract) [刘镇盛, 王春生, 张志南, 蔡昱明, 张东声 (2005) 乐清湾浮游动物的季节变动及摄食率. 生态学报, 25, 1853-1862.]

Magurran AE (1988) Ecological Diversity and Its Measurement. Chapman and Hall, London.

Ni YQ, Geng ZQ, Zhu JZ (2003) Study on characteristic of hydrodynamics in Hangzhou Bay. Journal of Hydrodynamics, 18, 439-445. (in Chinese with English abstract) [倪勇 强, 耿兆铨, 朱军政 (2003) 杭州湾水动力特性研讨. 水 动力学研究与进展, 18, 439-445.]

Pan YQ, Xu DR, Xu JQ (1985) The reason of surface structure changes in the Zhejiang coastal upwelling area. Acta Oceanologica Sinica, 7, 401-411. (in Chinese) [潘玉球, 徐 端蓉, 许建千 (1985) 浙江沿岸上升流区的锋面结构、变 化及其原因. 海洋学报, 7, 401-411.]

Pan YQ, Wang KS, Huang SS (1997) Analysis on the path of transportation and diffusion of Changjiang diluted water. Donghai Marine Science, 15(2), 25-34. (in Chinese with English abstract) [潘玉球, 王康墡, 黄树生 (1997) 长江 冲淡水输运和扩散途径的分析. 东海海洋, 15(2), 25-34.]

Shannon CE (1948) A mathematical theory of communication. Bell System Technical Journal, 27(3), 3-55.

Shen GY, Shi BZ (2002) Marine Ecology. Science Press, Beijing. (in Chinese) [沈国英, 施并章 (2002) 海洋生态学. 科学出版社, 北京. ]

Tian FG, Xu ZL (2012) Impact of seasonal variation of water masses on ecological characters of zooplankton in the coastal waters off central Fujian Province. Journal of Tropical Oceanography, 31, 107-114. (in Chinese with English abstract) [田丰歌, 徐兆礼 (2012) 福建中部近海浮游动 物生态特征与水团的关系. 热带海洋学报, 31, 107-114.]

Weng XC, Wang CM (1985) A study on Taiwan warm current water. Marine Sciences, 9(1), 7-10. (in Chinese with English abstract) [翁学传, 王从敏 (1985) 台湾暖流水的研究. 海洋科学, 9(1), 7-10.]

Xu JY, Liu SH, Xu ZL, Sun LF, Chen JJ (2014) Responses of zooplankton community to changes in water masses in the Sansha Bay. Chinese Journal of Applied and Environmental Biology, 20, 869-876. (in Chinese with English abstract) [徐佳奕, 刘守海, 徐兆礼, 孙鲁峰, 陈佳杰 (2014) 三沙 湾浮游动物群落对水团季节变化的响应. 应用与环境生 物学报, 20, 869-876.]

Xu JY, Xu ZL (2013) Seasonal succession of zooplankton in Sansha Bay, Fujian. Acta Ecologica Sinica, 33, 1413-1424. (in Chinese with English abstract) [徐佳奕, 徐兆礼 (2013) 三沙湾浮游动物生态类群演替特征. 生态学报, 33 , 
1413-1424.]

Xu ZL (2006) Relationships between population characters of Undinula vulgaris (Copepoda) and environment in the East China Sea. Chinese Journal of Applied Ecology, 17, 107-112. (in Chinese with English abstract) [徐兆礼 (2006) 东海普通波水蚤种群特征与环境关系的研究. 应用生态 学报, 17, 107-112.]

Xu ZL (2007) Mathematical analysis on adaptation of Heteropoda to different temperature and salinity in the East China Sea. Journal of Fishery Sciences of China, 14, 932-938. (in Chinese with English abstract) [徐兆礼 (2007) 东海浮游 异足类环境适应分析. 中国水产科学, 14, 932-938.]

Xu ZL, Chen YQ (1989) Aggregated intensity of dominant species of zooplankton in autumn in the East China Sea and Yellow Sea. Chinese Journal of Ecology, 8(4), 13-15. (in Chinese with English abstract) [徐兆礼, 陈亚䨉 (1989) 东 黄海秋季浮游动物优势种聚集强度与鲐鲐渔场的关系. 生态学杂志, 8(4), 13-15.]

Xu ZL, Gao Q (2011) Optimal salinity for dominant copepods in the East China Sea, determined using a yield density model. Chinese Journal of Oceanology and Limnology, 29, 514-523.

Xu ZL, Jiang M, Chao M, Wang YL, Yuan Q, Chen YQ (2003a) Quantitative distribution of pelagic copepods in the East China Sea. Journal of Fisheries of China, 27, 256-264. (in Chinese with English abstract) [徐兆礼, 蒋玫, 昆敏, 王云龙, 袁骐, 陈亚瞧 (2003a) 东海浮游桡足类的数量 分布. 水产学报, 27, 256-264.]

Xu ZL, Shen XQ, Yuan Q, Chen YQ (2003b) Distribution characteristics of zooplankton in waters around Yangshan Islands in Hangzhou Bay. Journal of Fisheries of China, 27(Suppl.), 69-75. (in Chinese with English abstract) [徐兆 礼, 沈新强, 袁骐, 陈亚㫿 (2003b) 杭州湾洋山岛周围 海域浮游动物分布特征. 水产学报, 27(增刊), 69-75.]

Xu ZL, Wang YL, Bai XM, Chen YQ (1999) An ecological study on zooplankton in the Changjiang Estuary. Journal of Fishery Sciences of China, 6(5), 55-58. (in Chinese) [徐兆
礼, 王云龙, 白雪梅, 陈亚篧 (1999) 长江口浮游动物生 态研究. 中国水产科学, 6(5), 55-58.]

Yu CG, Chen XQ, Hu HY, Huang B, Zheng J, Qin T, Ning P (2011) Species composition and community structure characteristics of zooplankton in the Zhoushan Fishing Ground and its adjacent area. Acta Hydrobiologica Sinica, 35, 183-193. (in Chinese with English abstract) [俞存根, 陈小庆, 胡影琰, 黄备, 郑基, 覃涛, 宁平 (2011) 舟山 渔场及邻近海域浮游动物种类组成及群落结构特征. 水 生生物学报, 35, 183-193.]

Zhang D, Xu ZL (2012) Estimating optimal salinity and temperature of chaetognaths. Journal of the Marine Biological Association of the United Kingdom, 92, 1399-1407.

Zhang JP, Xu ZL, Wang Q, Chen YQ (2005) Ecological characteristics of zooplankton near the Jiuduansha waters of the Yangtze River Estuary. Journal of Shanghai Fisheries University, 14, 383-389. (in Chinese with English abstract) [张 锦平, 徐兆礼, 汪琴, 陈亚㫿 (2005) 长江口九段沙附近 水域浮游动物生态特征. 上海水产大学学报, 14 , 383-389.]

Zhang QL, Hou YJ, Yan TZ (2012) Inter-annual and inter-decadal variability of Kuroshio heat transport in the East China Sea. International Journal of Climatology, 32, 481-488.

Zhao RX, Liu ZL (2014) The seasonal variation of the Kuroshio subsurface water intrusion northeast of Taiwan. Acta Oceanologica Sinica, 36, 20-27. (in Chinese with English abstract) [赵瑞祥, 刘志亮 (2014) 台湾东北部黑潮次表 层水入侵的季节变化规律. 海洋学报, 36, 20-27.]

Zheng Z, Li SJ, Xu ZZ (1984) Marine Planktology. China Ocean Press, Beijing. (in Chinese) [郑重, 李少菁, 许振祖 (1984) 海洋浮游生物学. 海洋出版社, 北京.]

Zhu QQ (1988) An investigation on the ecology of zooplankton in Changjiang Estuary and Hangzhou Bay. Journal of Fisheries of China, 12, 111-123. (in Chinese with English abstract) [ 朱启琴 (1988) 长江口、杭州湾浮游动物生态调查 报告. 水产学报, 12, 111-123.] 